\title{
MENGENAL BURNOUT PADA GURU
}

\author{
Oleh: Ulfiani Rahman
}

\begin{abstract}
In doing daily activities, as individual works in the public relation, sometimes faces some choices. The individual often gets conflict because of the choices. If the conflict appears but it cannot be overcome, it can arise stress. If the individual get long stress, he can be attacked by burnout syndrome. Therefore, everyone need to understand what burnout meant, what the characteristic of someone who gets burnout is, what influencing the appearance this syndrome, what aspects covering and how its psychological dynamic. The important thing explained that the individual can know earlier and avoid the syndrome attack.
\end{abstract}

KEYWORDS: Burnout, depresi, stres, psychological

SETIAP orang memiliki berbagai dorongan dan kebutuhan pokok yang bersifat organis (fisis dan psikis) serta bersifat sosial. Tanpa disadari semuanya menuntut pemuasan. Manakala tidak segera dipenuhi, maka dapat menimbulkan ketegangan. Apalagi bagi seseorang yang bekerja di bidang pelayanan seperti perawat, polisi, sales, dan guru. Ketegangan tersebut bisa merupakan cermin dari ketidakmampuan seseorang menghadapi keterbatasannya sehingga muncul rasa gelisah, frustasi, rasa bersalah sampai pada rasa cemas yang melumpuhkan. Hal ini dapat menimbulkan stres dalam kerja.

Menurut Wilson dan Corlett, ada tiga penyebab munculnya stres kerja, yakni: 1) pekerja dihadapkan pada tuntutan yang tidak sesuai dengan kemampuannya; 2) pekerja memiliki keterbatasan dalam mengatasi masalahnya; dan 3) dukungan yang kurang dari kolega, penyelia, teman atau keluarga. ${ }^{1}$

Dengan demikian stres kerja merupakan bentuk tanggapan seseorang baik secara fisis maupun mental terhadap suatu perubahan di lingkungan yang dirasakan mengganggu dan mengakibatkan dirinya terancam. ${ }^{2}$ Stres yang berkepanjangan dapat menimbulkan depresi dan jika segera dapat diatasi, maka tidak akan berlangsung lama. Akan tetapi, jika berlangsung lama dan cenderung menetap bisa membuat seseorang terkena sindrom burnout yakni kondisi emosional dimana seseorang merasa lelah dan jenuh, 
baik secara fisis maupun mental, sebagai akibat dari tuntutan pekerjaan yang meningkat.

Kelelahan mental merupakan perasaan yang kurang menyenangkan, perasaan resah, dan capai yang menguras seluruh minat dan tenaga, merasa tidak kompeten bahkan tidak berharga dan kelelahan ditimbulkan oleh pelaksanaan dari kegiatan yang tidak menarik, monoton serta berulangulang. ${ }^{3}$

Kelelahan dapat menyerang siapa saja, terutama yang berprofesi sebagai pelayan kemanusiaan seperti guru. Hal ini terjadi sebab guru banyak memberikan layanan pendidikan kepada para siswa dan merupakan pekerjaan yang menghadapi tuntutan dan pelibatan emosional.4 Pada jenis pekerjaan tersebut, seseorang menghadapi tuntutan dari klien atau siswa, tingkat keberhasilan dari pekerjaan rendah dan kurangnya penghargaan yang adekuat terhadap kinerja pemberi layanan. Pada akhirnya seseorang akan merasa lelah sebab ia berusaha memberikan sesuatu secara maksimal, tetapi memperoleh apresiasi yang minimal. Dengan kata lain, pekerjaan tersebut kurang mendapat respon yang positif di lingkungan kerja.

Hal di atas terkait dengan hasil penelitian yang dilakukan oleh Imelda Novelina Sihotang yang menemukan bahwa terdapat hubungan negatif antara persepsi karyawan terhadap lingkungan kerja psikologisnya dengan burnout, dengan sumbangan efektif sebesar 6,34\%. ${ }^{5}$ Hal ini dapat diartikan bahwa semakin baik persepsi karyawan terhadap lingkungan kerja psikologisnya semakin rendah pula gejala burnout yang mungkin mendekatinya. Meskipun demikian, masih ada faktor lain yang berpengaruh terhadap gejala burnout yakni faktor internal berupa usia, harga diri, dan karakteristik kepribadian.

Lebih lanjut Zakiah Daradjat mengemukakan bahwa seorang guru adalah seorang pelayan yang dituntut untuk selalu memiliki tingkah laku yang positif misalnya penyabar, penuh perhatian, hangat, humoris dan yang paling penting memiliki rasa empati. ${ }^{6}$ Walaupun begitu, seorang guru terkadang dihadapkan pada pengalaman negatif dengan siswa sehingga menimbulkan ketegangan emosional. Situasi seperti ini jika berlangsung secara terus menerus dapat menguras sumber energi guru. Sehingga kelelahan emosional dapat menghinggapinya dan ini merupakan sindrom burnout.

Ditegaskan oleh Farber bahwa yang berperan menimbulkan burnout pada guru adalah keacuhan siswa, ketidakpekaan penilik/pengawas sekolah, orangtua siswa yang tidak peduli, kurangnya apresiasi masyarakat terhadap pekerjaan guru, bangunan fisik sekolah yang tidak baik, 
hilangnya otonomi, dan gaji yang tidak memadai. ${ }^{7}$

Shinn dkk. mengemukakan bahwa burnout merupakan tekanan psikis yang dirasakan oleh seseorang yang bekerja di lingkungan yang melibatkan banyak orang. ${ }^{8}$ Apalagi jika pekerjaan tersebut dilakukan oleh orang yang memiliki komitmen berlebihan dan melibatkan diri dalam pekerjaan, tentu akan merasa kecewa jika tidak berimbang antara usaha yang dilakukan dan imbalan yang diterima. Hal ini bisa menimbulkan rasa gagal dan berdampak pada menurunnya penilaian terhadap kompetensi diri dan memicu munculnya rasa kurang percaya diri.

Individu yang dihinggapi rasa kurang percaya diri menunjukkan adanya penilaian terhadap diri yang rendah, dan ini menunjukkan bahwa individu tersebut memiliki harga diri yang rendah. Jika ditarik dalam konteks kesehatan mental, maka harga diri memiliki peran yang penting bagi individu untuk melakukan interaksi sosial dengan orang lain.

Seorang guru yang memiliki harga diri rendah cenderung memandang dirinya secara negatif dan terfokus pada kelemahan dirinya dan tidak mampu menjalin komunikasi yang baik dengan lingkungannya. Hal ini terjadi disebabkan ia keliru mengartikan pemikiran yang diterimanya serta ia bersikap pasif, kurang yakin akan kemampuannya, pesimis, dan rendah diri. ${ }^{9}$ Seseorang yang memiliki harga diri yang rendah berarti memiliki konsep diri yang rendah pula. Sedangkan seorang yang memiliki konsep diri rendah rentan terhadap burnout. Hal ini terkait dengan hasil penelitian yang dilakukan oleh Rina Amelia dan Zulkarnain yang menemukan terdapat hubungan yang negatif antara konsep diri dengan tingkat burnout dengan kontribusi sebesar 34\%. ${ }^{10}$ Artinya, masih ada faktor lain yang cukup berpengaruh terhadap burnout, seperti usia dan harga diri.

Sedangkan seorang guru yang memiliki harga diri tinggi berarti memandang dirinya secara positif. Sadar akan kelebihan yang dimilikinya dan memandang bahwa kelebihan tersebut lebih penting dari pada kelemahannya. Guru yang demikian akan mudah melakukan pekerjaan secara terencana tanpa menirukan orang lain. Di samping itu, tingkah laku yang ditampilkan pun lebih aktif, ekspresif, dan lebih percaya diri serta tidak mudah cemas. Menurut Hurlock, individu akan berbahagia dan memiliki kemampuan penyesuaian diri yang baik bila ia dapat menerima dan berdamai dengan dirinya sendiri. ${ }^{11}$

Dari uraian di atas tampak bahwa tujuan yang bisa dicapai adalah setiap orang dapat memahami dan mengenal burnout sejak dini sehingga dapat mengantisipasi munculnya ketika merasakan syndrom burnout menghampiri. 


\section{BURNOUT}

Burnout bukan suatu penyakit. Burnout dapat terjadi pada semua tingkatan individu dan merupakan pengalaman yang bersifat psikologis sebab melibatkan perasaan, sikap, motif, harapan, dan persepsi individu sebagai pengalaman negatif yang mengacu pada situasi yang menimbulkan ketegangan, tekanan, stres, dan ketidaknyamanan. Terkait dengan semua itu, terdapat beberapa pemaparan tentang burnout.

\section{Pengertian Burnout}

Freudenberger dan Richelson mendefinisikan burnout sebagai suatu keadaan yang dialami seseorang berupa kelelahan atau frustrasi sebab merasa bahwa apa yang diharapkannya tidak tercapai. ${ }^{12}$

Ditegaskan pula oleh Leatz dan Stolar bahwa burnout adalah kelelahan fisik, mental, dan emosional sebab stres yang dialami berlangsung dalam waktu lama dengan situasi yang menuntut adanya keterlibatan emosi yang tinggi serta tingginya standar keberhasilan pribadi. ${ }^{13}$

Sejalan dengan pengertian di atas, Cary Cherniss mengemukakan bahwa burnout merupakan perubahan sikap dan prilaku dalam bentuk reaksi menarik diri secara psikologis dari pekerjaan. ${ }^{14}$ Seperti menjaga jarak dengan klien maupun bersikap sinis dengan mereka, membolos, sering terlambat, dan keinginan pindah kerja yang kuat.

Ayala Pines dan Elliot Aronso secara spesifik menemukan bahwa burnout adalah kelelahan secara fisik berupa kelelahan yang bersifat sakit fisik dan energi fisik, kelelahan mental berupa kelelahan yang ditandai dengan rendahnya penghargaan terhadap diri dan depersonalisasi, serta kelelahan emosional berhubungan dengan perasaan pribadi yang ditandai dengan rasa tidak berdaya dan depresi. ${ }^{15}$

Sementara Cicilia Maslach mengungkapkan bahwa burnout memiliki pengertian yang multidimensional, berupa syndrom psikologis yang terdiri atas tiga dimensi yakni kelelahan emosional, depersonalisasi, dan low personal accomplishment. ${ }^{16}$

Dari beberapa definisi di atas dapat ditarik benang merah bahwa burnout adalah kondisi akhir dari stres yang dapat berbentuk kelelahan fisik, kelelahan mental, kelelahan emosional, depersonalisasi, dan berkurangnya penghargaan terhadap diri sendiri sebagai akibat dari keterlibatan jangka panjang pada situasi interpersonal yang menuntut.

\section{Ciri-ciri Burnout}

Ada beberapa ahli yang mencoba mengidentifikasi ciri-ciri dari individu yang mengalami burnout. Di antara ahli itu adalah Cerniss yang 
mengemukakan bahwa gejala burnout dapat dilihat dari adanya ciri-ciri berikut: 1) resistensi yang tinggi untuk pergi bekerja setiap hari; 2) terdapat perasaan gagal dalam diri; 3) cepat marah dan sering kesal; 4) rasa bersalah dan meyalahkan; 5) keengganan dan ketidakberdayaan; 6) negatifisme; 7) isolasi dan penarikan diri; 8) perasaan capek dan lelah setiap hari; 9) sering memperhatikan jam saat bekerja; 10) sangat pegal setelah bekerja; 11) hilang perasaan positif; 12) menunda kontak dengan klien; 13) menyamaratakan klien; 14) tidak mampu menyimak apa yang klien katakan; 15) susah tidur; 16) asyik dengan diri sendiri; 17) menghindari diskusi tentang pekerjaan dan teman kerja; 18) sering sakit kepala dan gangguan pencernaan; 19) kaku dalam berpikir dan resisten terhadap perubahan; 20) paranoid; dan 21) sangat sering membolos. ${ }^{17}$

Pendapat di atas hampir sejalan dengan pendapat Freudenberger dan Richelson yang mengidentifikasi 11 gejala burnout, yaitu: 1) kelelahan yang disertai keletihan sebab merupakan proses kehilangan energi; 2) lari dari kenyataan; 3) mengalami kebosanan dan sinisme; 4) tidak sabaran dan mudah tersinggung; 5) merasa hanya dirinya yang bisa menyelesaikan masalah; 6) merasa tidak dihargai; 7) mengalami disorientasi; 8) adanya keluhan psikosomatis; 9) curiga tanpa alasan; 10) depresi; dan 11) penderita menyangkal kenyataan yang dihadapi. ${ }^{18}$

Sementara itu Ayala dan Pines mengklasifikasikan ciri-ciri burnout menjadi tiga bagian, yaitu:

1. Kelelahan fisik seperti sakit kepala, demam, sakit punggung, rentan terhadap penyakit, tegang pada otot leher dan bahu, sering terkena flu, susah tidur, mual-mual, gelisah, dan perubahan kebiasaan makan.

2. Kelelahan emosi seperti rasa bosan, mudah tersinggung, sinisme, perasaan tidak menolong, ratapan yang tiada henti, tidak dapat dikontrol (mudah marah), gelisah, tidak perduli terhadap tujuan, tidak peduli dengan peserta didik (orang lain), merasa tidak memiliki apa-apa untuk diberikan, sia-sia, putus asa, sedih, tertekan dan tidak berdaya.

3. Kelelahan mental, seperti merasa tidak berharga, rasa benci, rasa gagal, tidak peka, sinis, kurang bersimpati dengan orang lain, mempunyai sikap negatif terhadap orang lain, cenderung masa bodoh dengan dirinya, pekerjaannya dan kehidupannya, acuh tak acuh, pilih kasih, selalu menyalahkan, kurang bertoleransi terhadap yang ditolong, ketidakpusan terhadap pekerjaan, konsep diri yang rendah, merasa tidak kompeten dan tidak puas dengan jalan hidup. ${ }^{19}$

\section{Faktor-faktor yang Mempengaruhi Burnout}

Menurut Simamora, faktor-faktor yang mempengaruhi burnout antara lain: 1) kurangnya dukungan sosial dari atasan; 2) imbalan yang diberikan tidak mencukupi atau tidak tepat; 3) pekerjaan yang berulang- 
ulang atau memberikan sedikit ruang gerak bagi kreativitas; 4) kondisi kerja yang tidak menyenangkan atau menekan; 5) pekerjaan yang monoton atau tidak variatif. ${ }^{20}$

Sementara itu, Baron dan Greenberg membagi faktor-faktor yang mempengaruhi burnout ada dua, yaitu:

1. Faktor eksternal berupa kondisi organisasi kerja, yang meliputi: kondisi lingkungan kerja yang kurang baik, kurangnya kesempatan untuk promosi, adanya prosedur serta aturan yang kaku yang membuat orang merasa terjebak dalam sistem yang tidak adil, gaya kepemimpinan yang diterapkan supervisor kurang memperhatikan kesejahteraan karyawan, dan tuntutan pekerjaan;

2. Faktor internal adalah kondisi yang berasal dari diri individu, meliputi: jenis kelamin, usia, harga diri, tingkat pendidikan, masa kerja dan karakteristik kepribadian serta kemampuan penanggulangan terhadap stres (coping with stress). ${ }^{21}$

\section{Aspek-aspek Burnout}

Maslach mengemukakan bahwa terdapat tiga dimensi burnout, yaitu:

1. Kelelahan emosional yang ditandai dengan perasaan frustasi, putus asa, sedih, tidak berdaya, tertekan dan merasa terjebak, mudah tersingung dan mudah marah tanpa alasan yang jelas;

2. Depersonalisasi, ditandai dengan menjauhnya individu dari lingkungan sosial, apatis, tidak peduli terhadap lingkungan dan orang-orang yang ada di sekitarnya;

3. Rendahnya penghargaan terhadap diri sendiri, yakni individu tidak pernah merasa puas dengan hasil karyanya sendiri, merasa tidak pernah melakukan sesuatu yang bermanfaat bagi dirinya maupun orang lain. ${ }^{22}$

Sementara itu, Baron dan Greenberg juga mengemukakan empat aspek burnout, yaitu:

1. Kelelahan fisik yang ditandai dengan serangan sakit kepala, mual, susah tidur, dan kurangnya nafsu makan;

2. Kelelahan emosional, ditandai dengan depresi, perasaan tidak berdaya, merasa terperangkap dalam pekerjaannya, mudah marah serta cepat tersinggung;

3. Kelelahan mental, ditandai dengan bersikap sinis terhadap orang lain, bersifat negatif terhadap orang lain, cenderung merugikan diri sendiri, pekerjaan, organisasi dan kehidupan pada umumnya;

4. Rendahnya penghargaan terhadap diri, ditandai dengan tidak pernah puas terhadap hasil kerja sendiri, merasa tidak pernah melakukan sesuatu yang bermanfaat bagi dirinya maupun orang lain..$^{23}$ 
Sedangkan Pines dan Aronson mengemukan bahwa terdapat tiga aspek dari burnout yakni:

1. Kelelahan fisik, yaitu kelelahan yang terkait dengan fisik dan energi fisik. Sakit fisik seperti sakit kepala, demam, sakit punggung, rentan terhadap penyakit, tegang pada otot leher dan bahu, sering terkena flu, susah tidur, mual-mual, gelisah, dan perubahan kebiasaan makan. Sementara energi fisik dicirikan sebagai energi yang rendah, rasa letih yang kronis, dan lemas;

2. Kelelahan emosi adalah kelelahan yang berhubungan dengan perasaan pribadi seperti, putus asa, mudah tersinggung, tidak peduli pada tujuan, depresi, dan tidak berdaya;

3. Kelelahan mental adalah menyangkut rendahnya penghargaan diri dan depersonalisasi. Cirinya merasa tidak berharga, tidak cakap, tidak kompeten, dan tidak puas terhadap pekerjaan. ${ }^{24}$

Dengan demikian, dapat dipahami bahwa ketiga pendapat di atas memiliki kemiripan pandangan, sehingga dapat disimpulkan bahwa dimensi-dimensi dari burnout dapat dibagi menjadi 5 aspek, meliputi: kelelahan fisik, kelelahan mental, kelelahan emosional, depersonalisasi, dan rendahnya penghargaan terhadap diri.

\section{TINGKAT BURNOUT PADA GURU}

Manusia sebagai makhluk sosial memiliki kecenderungan untuk senantiasa berbagi kepada sesamanya secara seimbang. Dalam arti saling menghormati dan saling menghargai sehingga akan mudah dalam menjalin komunikasi dimana pun berada.

Banyak orang yang dalam hidupnya kurang mampu menyesuaikan diri dengan lingkungannya. Hal ini dapat dilihat dari besarnya harapan seseorang terhadap lingkungannya untuk memenuhi kebutuhan dirinya. Tingginya harapan ini kadang tidak sesuai dengan kenyataan sehingga seseorang dapat mengalami rasa kecewa. Kekecewaan berlebihan dapat menimbulkan stres dan ketika stres tidak dapat diatasi dan berlangsung dalam jangka waktu yang lama, maka boleh jadi terkena sindrom burnout. Artinya, seseorang yang tidak mampu menghadapi masalah yang menimpanya boleh jadi akan dihinggapi rasa lelah baik fisik, mental, maupun emosional.

Ciri dari kelelahan emosi yang mungkin menghinggapi adalah perasaan putus asa, sedih, tidak berdaya, terbelenggu terhadap pekerjaan sehingga seorang guru tidak mampu memberikan pelayanan secara psikologis seperti marah-marah tanpa alasan yang jelas, menjauh dari lingkungan sosial, cenderung tidak peduli pada lingkungan, kehilangan 
idealisme, mengurangi kontak dengan siswa, rendahnya keinginan untuk berprestasi ditandai perasaan tidak puas pada diri sendiri, pekerjaan bahkan kehidupan serta ia merasa bahwa ia belum pernah melakukan sesuatu yang bermanfaat.

Jika hal ini terjadi, individu akan merasa tidak memiliki motivasi untuk melakukan pekerjaan sebab semua menjadi serba salah. Individu yang selalu menyalahkan dirinya, tanpa mampu melihat secara realistis keadaan yang menimpanya, menunjukkan rendahnya pernghargaan terhadap dirinya sendiri. Ia berusaha bekerja di luar dari kemampuannya dan hal ini sama artinya ia memaksakan diri untuk meraih sesuatu yang sulit.

Tingginya standar yang ditetapkan untuk melakukan suatu tugas menunjukkan tingginya harga yang ditetapkan seseorang tersebut pada dirinya. Namun, jika tidak dibarengi dengan perencanaan yang matang boleh jadi justru menjadi bumerang dalam melakukan aktivitas sebab tidak sesuai dengan apa yang seharusnya. ${ }^{25}$ Ia menjadi putus asa, tidak berharga, ingin lari dari lingkungannya, mau menyendiri, dan segudang keinginan lainnya yang tidak realistis.

Menurut Adler, sifat kepribadian yaitu individualitas, kualitas, serta sifat pribadi manusia. Menurutnya, setiap orang adalah suatu konfigurasi mutu, sifat serta nilai-nilai yang khas, tetapi tindakan yang dilakukan oleh seseorang membawa corak khas gaya kehidupannya yang bersifat individual. ${ }^{26}$ Dengan kata lain, manusia adalah individu yang unik. Keunikannya tercermin dalam situasi, pengalaman, impian dan masalah kehidupan yang sama mempunyai dampak fisik dan emosional yang berbeda pada masingmasing orang. ${ }^{27}$

Profesi sebagai guru secara tidak langsung menuntut tingginya harga diri pada seseorang sebab akan selalu berhubungan dengan pelayanan. Dan pelayanan yang baik hanya akan muncul dari pribadi-pribadi yang sehat secara mental. Sebaliknya dengan harga diri yang rendah diletakkan di diri seseorang menunjukkan kekurangmampuan berempati.

Harga diri bukan suatu sifat bawaan yang tidak dapat diubah, ia dipengaruhi oleh berbagai faktor seperti suasana jiwa, kondisi kesehatan, kemalangan atau kehilangan orang yang dicintai, kehilangan pekerjaan, pensiun dan lain-lain. Banyak orang yang harga dirinya rendah cenderung mudah terjerumus ke dalam kekalutan emosional yang membuat mereka tidak memiliki persepsi yang sehat mengenai diri maupun lingkungan eksternalnya. ${ }^{28}$

Seseorang yang memiliki harga diri rendah biasanya menjadi pemicu munculnya burnout dalam bekerja. Apalagi jika tidak mendapat dukungan sosial tentu burnout akan sangat mudah menghinggapi seorang guru. 
Penelitian Rita Andarika menemukan bahwa terdapat hubungan yang negatif antara dukungan sosial dengan tingkat burnout pada perawat puteri. Semakin tinggi dukungan sosialnya semakin rendah tingkat burnout-nya. ${ }^{29}$ Demikian pula dengan hasil penelitian yang dilakukan oleh Farhati dan Rosyid yang mengungkapkan bahwa dukungan sosial yang baik serta karakteristik pekerjaan yang jelas memberikan kontribusi positif dalam menurunkan tingkat burnout. Hal ini juga tidak terlepas dari adanya rentetan harga diri yang dimiliki oleh seseorang yang akan memberikan kontribusi untuk mendapatkan dukungan sosial yang penuh, baik dari rekan kerja maupun dari atasan. Dukungan sosial yang didapat dari rekan kerja jarang menunjukkan gejala depersonalisasi yaitu coping (proses mengatasi ketidakseimbangan antara tuntutan dan kemampuan individu) untuk mengatasi kelelahan emosional.

Dari hasil tersebut di atas umumnya masih mengharapkan adanya penelitian lanjutan tentang pengaruh faktor internal, seperti harga diri, terhadap tingkat burnout pada seseorang seperti guru. Sebab, disinyalir bahwa harga diri memiliki pengaruh yang besar dalam mempertahankan seseorang melakukan pekerjaannya. Adanya penilain yang baik terhadap diri di lingkungan kerja tentu akan membuat pekerjaan tersebut tidak akan sulit dijalani. Kemampuan individu menghargai dirinya akan membantu individu dalam melakukan interaksi dengan orang lain sehingga terwujud keharmonisan hidup.

\section{PENUTUP}

Jika melihat situasi saat ini yang ditandai dengan semakin majunya sains dan teknologi memacu laju perubahan yang tidak terelakkan di masyarakat secara signifikan. Hal ini tentu saja berdampak pada pentingnya memiliki kemampuan menyesuaikan diri apalagi bagi seseorang yang berprofesi sebagai guru. Guru memerlukan berbagai kesiapan baik fisik, mental, maupun emosi dalam menghadapinya. Sebab, jika tidak demikian, maka guru tersebut sangat mungkin dihinggapi stres yang melebihi daya tahannya dan jika bertahan lama dapat menimbulkan burnout.

Pekerjaan sebagai guru membutuhkan kemampuan adaptasi yang tinggi sebab sifat pekerjaan yang mengharuskannya selalu berkomunikasi

dengan orang lain terutama siswa. Para siswa tersebut memiliki perbedaan satu sama lainnya. Hal ini berdampak pada prilaku mereka dalam menyikapi situasi belajar. Jika tidak sanggup menghadapinya, maka berbagai kesulitan akan memicu munculnya burnout.

Oleh karena itu, seorang guru perlu selalu fresh dengan cara menjaga kesehatan, melakukan refreshing, menjalin komunikasi yang baik kepada orang lain, meningkatkan wawasan terutama yang terkait dengan tata 
laksana proses belajar dan mengajar seperti, membaca, menulis, mengikuti kegiatan yang menunjang keberhasilan pengajaran dan yang lebih penting adalah mendekatkan diri kepada Tuhan.

\section{CATATAN AKHIR}

1. J. R. Wilson dan N. E. Corlett, Evaluation of Human Work: A Practical Ergonomics Methodology, London: Taylor and Francis, 1992, h. 36.

2. Panji Anoraga, Psikologi Kerja, Jakarta: Rieneka Cipta, 1998, h. 108.

3. Panji Anoraga, Psikologi Kerja, h. 110.

4. Uus Firdaus, Pikiran Rakyat, 24 Maret 2006.

5. Imelda Novelina Sihotang, Burnout pada Karyawan ditinjau dari Persepsi terhadap Lingkungan Kerja Psikologis dan Jenis Kelamin, Jurnal Psyche,Vol. 1. No.1 - Juli 2004, h. 5

6. Zakiah Daradjat, Kepribadian Guru, Jakarta: Bulan Bintang, 1980, h. 17.

7. Barry A. Farber, Crisis in Education: Stress and Burnout in the American Teacher, San Fransisco: Jossey-Bass Publisher, 1991, h. 15.

8. Lihat dalam F. Farhati dan H. F. Rosyid, Karakteristik Pekerjaan, Dukungan Sosial \& Tingkat Burnout pada Non Human Service Corporation, Jurnal Psikologi, 1996, No I. 1-12, h. 2,3

9. Burns, Konsep diri: Teori, Pengukuran, Perkembangan, dan Prilaku, Arcan, 1993, h. 69.

10. Rita Amelia \& Zulkarnain, Konsep Diri dan Tingkat Burnout Pada Karyawan Yang Bekerja di Instansi Pelayanan Masyarakat, Psikologika No. 19 Tahun X. Januari 2005.

11. Elizabeth B. Hurlock, Psikologi Perkembangan: Suatu Pendekatan Sepanjang Rentang Kehidupan, Ed. VI, Jakarta: Airlangga, 1996, h. 357-359.

12. Lihat F. Farhati dan H. F. Rosyid, Karakteristik Pekerjaan, Dukungan Sosial, \& Tingkat Burnout pada Non Human Service Corporation, h. 9-10.

13. C. A. Leatz dan M. W. Stolar, When Work Gets To Be Too Much, World Executives Digest, 1993, h. 11.

14. Lihat Sutjipto, Apakah Anda Mengalami Burnout?, www.Depdiknas.Com, h. 3.

15. Lihat Kartini Kartono, Hygiene Mental, Bandung: Mandar Maju, 2000, h. 215.

16. Cicilia Maslach dalam Sutjipto, Apakah Anda Mengalami Burnout? www.Depdiknas.Com, h. 3.

17. Lihat Sutjipto, Apakah Anda Mengalami Burnout?, h. 6.

18. F. Farhati, Peran Tingkat Karakteristik Pekerjaan dan Dukungan Sosial terhadap Tingkat Burnout Karyawan Radian Utama Group Jakarta, Skripsi (tidak diterbitkan), Yogyakarta: Fakultas Psikologi Universitas Gadjah Mada, 1996, h. 20.

19. Ayala Pines and Elliot Aronso, Career Burnout: Causes and Cures, New York: The Free Press, A Division of Mcmillan. Inc., 1989, h. 25.

20. H. Simamora, Manajemen Sumber Daya Manusia, Yogyakarta: STIE YKPN, 1995, h. 15

21. Jerald Greenberg dan A. Baron, Behavior in Organization, Understanding and 
Managing the Human side of Work, ed. V, New Jersey: Prentice Hall inc. Englewood Cliff, 1993, h. 58.

22. Cicilia Maslach dalam Sutjipto, Apakah Anda Mengalami Burnout?, www.Depdiknas.Com, h. 2.

23. Jerald Greenberg dan A. Baron, Behavior in Organization, Understanding and Managing the Human side of Work, h. 60.

24. Ayala Pines and Elliot Aronso, Career Burnout: Causes and Cures, h. 30.

25. Barbara De Angelis, Confidence: Percaya Diri Sumber Sukses dan Kemandirian, Jakarta: Gramedia Pustaka Utama, 2000, h. 4-5.

26. Lihat S. Hall Calvin dan Lindzey Gardner, Tori-teori Psikodinamik, Yogyakarta: Kanisius, 1993, h. 239-249.

27. S. Prihanto, Thematic Apperception Test, (Handout), Fak. Psikologi Universitas Surabaya, 1999, h. 21.

28. F. Calhoun James dan Joan Ross Acocella, (terjemahan), Psikologi tentang Penyesuaian dan Hubungan Kemanusiaan, Semarang: IKIP Semarang Press, 1995,

29. R. Andarika, Burnout pada Perawat Putri RS Elizabeth Semarang Ditinjau dari Dukungan Sosial, Jurnal Psyche.Vol 1. No. 1, Juli 2004.

\section{DAFTAR PUSTAKA}

Amelia, R. dan Zulkarnain, Konsep Diri dan Tingkat Burnout pada Karyawan yang Bekerja di Instansi Pelayanan Masyarakat, Psikologika, No. 19 Tahun X. Januari 2005.

Andarika, R., Burnout pada Perawat Putri RS Elizabeth Semarang Ditinjau dari Dukungan Sosial, Jurnal Psyche,Vol 1. No. 1, Juli 2004.

Angelis, Barbara De, Confidence: Percaya Diri Sumber Sukses dan Kemandirian, Jakarta: Gramedia Pustaka Utama, 2000.

Aronaga, P., Psikologi Kerja, Jakarta: Rieneka Cipta, 1998.

Burns, R. B., Konsep Diri, Jakarta: Penerbit Arca, 1993.

Calvin, S. Hall dan Lindzey Gardner, Tori-teori Psikodinamik, Yogyakarta: Kanisius, 1993.

Daradjat, Zakiah, Kepribadian Guru, Jakarta: Bulan Bintang, 1980.

Farber, Barry A., Crisis in Education: Stress and Burnout in the American Teacher, San Fransisco: Jossey-Bass Publisher, 1991.

Farhati, F., Peran Tingkat Karakteristik Pekerjaan dan Dukungan Sosial terhadap Tingkat Burnout Karyawan Radian Utama Group Jakarta, Skripsi, tidak diterbitkan, Yogyakarta: Fakultas Psikologi Universitas Gadjah Mada, 1996.

Farhati, F. dan Rosyid, H. F., Karakteristik Pekerjaan, Dukungan Sosial, dan Tingkat Burnout pada Non Human Service Corporation, Jurnal Psikologi, 1996, No. I, 1-12.

Firdaus, U., Burnout, Pikiran Rakyat, Tanggal 23 Maret 2006, www.google.com.

Freudenberger, H. J. dan Richelson, E., Burnout: How to Beat the High Coast of Success, New York: Bantam Book, 1981.

Greenberg, Jerald dan A. Baron, Behavior in Organization, Understanding and Managing the Human side of Work, edisi kelima, New Jersey: Prentice Hall inc., Englewood Cliff, 1993. 
Hurlock, E. B., Psikologi Perkembangan: Suatu Pendekatan Sepanjang Rentang Kehidupan, edisi keenam, Jakarta: Airlangga, 1996.

Leatz, C. A., dan M. W. Stolar, When Work Gets to be Too Much, World Executives Digest, 14, 11.11, 1993.

Maslach, C., Burnout the Cost of Caring, New Jersey: Prentice-Hall. Inc., 1982.

Simamora, H., Manajemen Sumber Daya Manusia, Yogyakarta: STIE YKPN, 1995.

Sihotang, I. N., Burnout pada Karyawan Ditinjau dari Persepsi terhadap Lingkungan Kerja Psikologis dan Jenis Kelamin, Jurnal Psyche,Vol 1. No. 1, Juli 2004.

Sutjipto, Apakah Anda Mengalami Burnout? www.depdiknas.com.

Suryabrata, S., Psikologi Kepribadian, Jakarta: CV. Rajawali, 1982.

Paulina, M., Harga Diri dan Strategi Mengahadapi Masalah pada Remaja Penyalahguna Narkoba, Skripsi (tidak diterbitkan), Fak. Psikologi Universitas Gadjah Mada, 1996.

Pines, Ayala and Elliot Aronso, Career Burnout: Causes and Cures, New York: The Free Press, A Division of Mcmillan. Inc., 1989.

Prihanto, S., Thematic Apperception Test, (Handout), Fak. Psikologi Universitas Surabaya, 1999.

Ramadhani, W. Y., Hubungan antara Dukungan Sosial dengan Harga Diri pada Remaja, Skripsi, (tidak diterbitkan), UST Yogyakarta, 2006.

Raymond, Harga Diri Remaja, www.e-psikologi.com, 2001.

Wilson, J. R., dan N. E. Corlett, Evaluation of Human Work: A Practical Ergonomics Methodology, London: Taylor and Francis, 1992. 